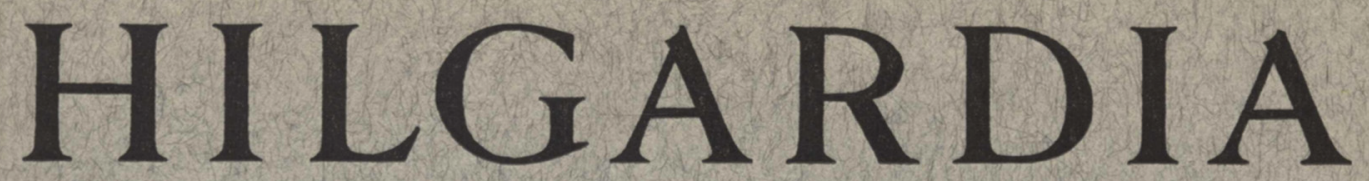

A Journal of Agricultural Science Publisbed by the California Agricultural Experiment Station

\title{
CONTENTS
}

\section{THE BRANCH WILT \\ OF PERSIAN WALNUT TREES \\ AND ITS CAUSE}

E. E. WILSON

UNIVERSITY OF CALIFORNIA - BERKELEY, CALIFORNIA 


\title{
H I $\quad$ I
}

A Journal of Agricultural Science Published by

the California Agricultural Experiment Station

\section{THE BRANCH WILT OF PERSIAN WALNUT TREES AND ITS CAUSE ${ }^{1}$}

\author{
E. E. WILSON ${ }^{2}$
}

\section{INTRODUCTION}

A BRANCH WILT DISEASE affecting Persian walnuts (Juglans regia L.) in California has been reported (Wilson, 1945, 1946). ${ }^{3}$ The trouble was first noticed about ten years ago in the southern San Joaquin Valley; but, according to some growers, it has been present in the Sacramento Valley for an equal length of time. Within the past five or six years it has become a major disease of certain walnut varieties throughout the central valleys.

\section{THE DISEASE}

Name. Growers call the disease "wilt," "limb wilt," "twig wilt," or "branch wilt." The fourth name seems preferable, since the outer branches, not the limbs or twigs, are most commonly affected and since the disease is not a wilting of the entire tree, as the term "wilt" might imply.

Symptoms. As would be inferred from the name, the principal manifestation of the malady is the wilting of certain branches. During July and August the leaves wither, turn a deep brown, dry up (plate 1, $A$, page 443), but remain attached to the twigs. Because wilted leaves are very conspicuous against the surrounding green foliage, the disease is easily detected in an orchard during late summer. Only one other malady that might be confused with the branch wilt has been encountered. This is a twig blight ${ }^{4}$ occurring in summer and suddenly withering the leaves on twigs; but it seldom if ever kills large branches in one season. Specimens of this other disease on small branches 1.0 to 1.5 inches in diameter were received from southern California; but in this instance evidently the disease first attacked a twig and then gradually extended to the branch, which it killed only after two or three years.

Once established in the outer branches, the branch wilt proceeds into the limbs (plate $1, B$ ) and within a few years may involve most of the treetop.

\footnotetext{
${ }^{1}$ Received for publication January 25, 1947.

${ }^{2}$ Associate Professor of Plant Pathology and Plant Pathologist in the Experiment Station.

${ }^{3}$ See "Literature Cited" for citations, which are referred to in the text by author and date.

- The status of this disease is being investigated. A Dothiorella sp., which may be $D$. gregaria, the cause of the melaxuma canker on walnut branches, is found on the recently blighted twigs.
} 
When this occurs, not only are certain limbs killed outright, but others are so weakened by the death of large areas of bark and wood that they develop sparse sickly foliage and eventually succumb.

For some time after this disease appeared in Tulare County, growers mistook it for the effects of crown rot, caused by Phytophthora cactorum, which produces a general decline of the tree. But trees without evidence of crown rot developed branch-wilt symptoms, although, as was learned later, those with crown rot or with armillaria root rot (caused by Armillaria mellea) are more liable to attack by branch wilt than healthy, vigorous trees.

The bark on a branch affected by wilt is dead and discolored. The necrotic area commonly originates on the upper side of the branch, sometimes at a sunburned spot or around an injury made by the hooks or poles in harvesting (plate $2, C$ ).

Wood underlying the diseased bark is dark gray to black (plate 2, $B$ ), and discoloration in the wood often extends up and down the branch well beyond the area of necrotic bark (plate $2, D$ ). Elements of affected wood are filled with a dark brown substance, and the vessels with many tyloses.

A noticeable feature of diseased branches is the loosening and sloughing away of the periderm, exposing large areas of cortical tissue that are covered by a dark brown to black powdery deposit (plate $2, A$ ). This deposit is composed of numerous dark brown fungus spores. So consistently are the loosening of the periderm and the presence of the sooty deposit associated with leaf-wilting symptoms, that these features serve to identify the disease even in winter, after the foliage has fallen.

Relation to Persian Walnut Varieties. Although the Franquette and Mayette varieties appear to be most subject to branch wilt, the Eureka is probably not much less susceptible. Others attacked are Payne, Meylan, Blackmer, and Bijou. The Concord, on the other hand, appears to possess some resistance, since in one orchard, trees of this variety were free of the disease though surrounded by badly affected trees of Franquette and Meylan.

The susceptibility of the Placentia and similar varieties is undetermined; few trees of these varieties are found in the districts where the disease is under observation.

Other Hosts. Although the native black walnuts Juglans hindsii Jepson and $J$. californica Wats. occur throughout California, and although the former, in particular, is used as a rootstock for Persian walnuts, only one wilted branch has been observed in these species. In one roadside planting near Winters, Yolo County, however, where wilt-affected Persian walnuts were interspersed between trees of $J$. hindsii, a few branches of the latter were found with the black spore deposit. These branches probably had been dead for a year, but the branch-wilt fungus was easily obtained in culture.

European chestnut trees, Castanea sativa Mill., about a mile northeast of wilt-affected walnut trees near Biggs, Butte County, developed typical branch-wilt symptoms in a few trees. Black spore deposits similar to those on walnut were found on these and on other branches that had died the summer before. The pathogenic and cultural characteristics of the fungus from chestnut are discussed later.

Wilting of the foliage in lemon trees (Citrus limonia Osb.) occurred in 
the Worth district, Tulare County, during the summer of 1946. According to the grower, the lemon trees were injured by freezing in 1938. The following year the more severely damaged branches were removed, but considerable areas of frost-injured bark remained in the tree. Wood rot, which developed in the cut-back limbs, probably caused the death of certain branches; but,

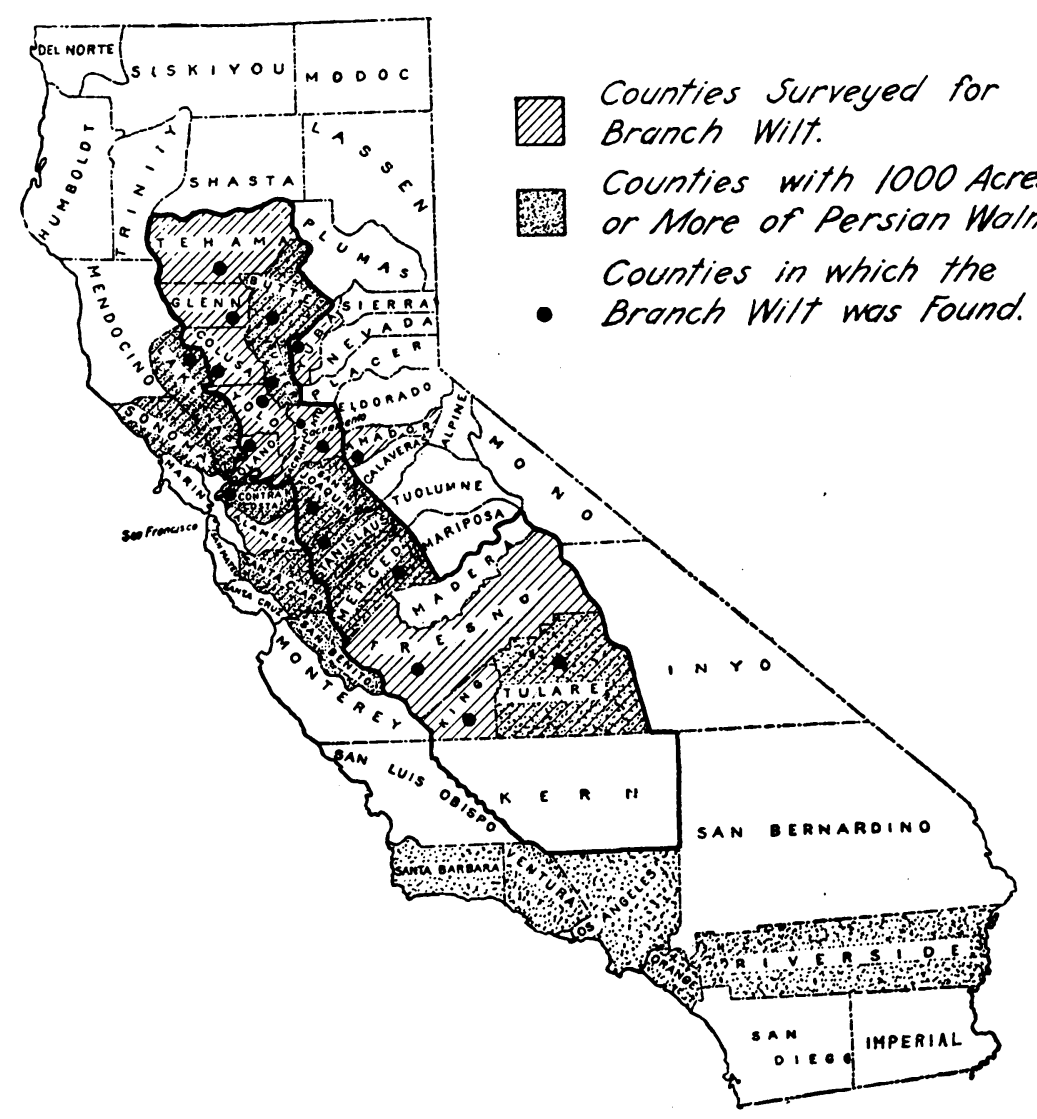

Fig. 1.-Map of California showing counties in which walnut branch wilt has been found.

for the most part, the wood of branches which died in 1946 was sound, though dry and discolored. A strip of bark along one side of the wilted branches had been dead for some time, presumably killed by freezing in 1938, but more recent necrosis of bark had occurred at the margins of these strips. Black layers of fungus spores were present beneath the periderm of recently killed bark, and gum exuded along the margins of the necrotic areas. Moreover, two branches with the diseased areas occurring only in tissue produced since the freeze, were found in one tree. A similar trouble was reported from this county in 1923 (Fawcett, 1936, p. 218) on frost-injured orange and grapefruit trees. Fawcett says of the disease: "Large branches are killed and dead bark-lesions also appear on the trunks, accompanied by 
much gum formation in large pockets under the bark." Fawcett also mentions the black spore deposits, but does not say in what manner nor at what time of year the branches died. The relation of this citrus disease to walnut branch wilt is considered in later sections.

Distribution in California. The map in figure 1 shows the major Persianwalnut-producing counties of the state. Walnut trees also occur in small groves or in roadside and border plantings in most agricultural districts. The Placentia and similar varieties are planted chiefly in the six southern counties, whereas Franquette, Mayette, and Payne are the chief varieties from Tulare County northward (Agricultural Adjustment Administration, 1936).

The area indicated by cross-hatching has been covered by the writer in a search for the branch wilt. Though the survey was not extended to the southern counties, agricultural representatives in that area were asked to send suspected material to our laboratory. Of the eight or more samples received, none proved to be branch wilt.

Within the area outlined on the map lie the San Joaquin and Sacramento valleys, where the search for the disease has been most intensive. Branch wilt is common in this area, occurring both in orchard plantings and on trees bordering roadsides and fields, but is most prevalent in Tulare County and along the Sacramento River in Colusa, Glenn, Butte, and Tehama counties. It also occurs on roadside trees in districts where walnuts are not grown commercially. On the other hand, the branch wilt was not found in important walnut districts of Sutter, San Joaquin, and Merced counties, though it is present in other sections of these counties.

Outside the interior valleys, the disease was found in Amador, Lake, and Contra Costa counties. Though of little consequence in the last county, in the other two it has done considerable damage to trees. No reports of the trouble were received from the coastal counties around San Francisco Bay, nor was it found by the writer on trips through Sonoma, Napa, Alameda, and Santa Clara counties.

Relation to Vigor of the Tree. Unthrifty trees are noticeably more subject to infection by branch wilt than vigorous ones. For example, as mentioned earlier, trees weakened by armillaria root rot or crown canker contract the disease more quickly and become involved by a more severe form of branch wilt than normal trees. In a certain orchard in Tehama County, eleven trees were sparse in foliage and obviously weak. At least three had been attacked by Armillaria mellea, while the rest bore symptoms of crown rot. During the 1945 season, branch wilt killed 88 branches in the weakened trees, but only 25 branches on a corresponding number of the surrounding vigorous trees.

Not uncommonly roadside trees which border unirrigated fields, and which therefore are subject to low soil moisture during the summer, are affected by branch wilt while near-by trees in irrigated orchards are free of the trouble. One case in particular involved a small orchard of Franquette trees that were visibly suffering from lack of soil moisture. Wilted branches were numerous in these trees, whereas in a well-cared-for Franquette orchard across the road to the east no branch wilt occurred. 
Relation to Sunburning of Branches. A relatively high proportion of cankers appear around areas of bark that have been injured by exposure to the sun. Sunburning is believed to account for the fact that the incidence of the disease is sometimes two to three times greater on the south than on the north side of the tree.

Relation to Age of Tree. Young walnut orchards that have received proper care are usually less affected by branch wilt than older orchards. This seems to hold true of trees up to the age of ten or even fifteen years. On the other hand, certain young replants in affected orchards have manifested severe branch-wilt symptoms.

\section{THE FUNGUS}

Fungi Isolated from Affected Walnut Branches. Species of Schizophyllum and Nectria are sometimes isolated from branches that have been dead from wilt for a year or more, but these fungi are seldom found in recently wilted branches. A Dothiorella species is particularly common on blighted twigs, and its relation to the death of walnut branches is receiving attention. Apparently, however, this Dothiorella invades branches slowly and therefore does not cause the extensive symptoms typical of branch wilt.

The black spore deposit beneath the branch periderm usually is present when the branch wilts; hence the association of this fungus with the external symptoms of the disease was easily established. Moreover, according to results from about two hundred isolations from numerous specimens collected at various places, the dark-spored fungus was found in the bark and wood of over 90 per cent of recently wilted branches. Mycelium was found in most xylem elements, including the ray cells. Hyphae pass from one element to the other through the pits. Single strands of mycelium were seen to traverse five or six ray cells and then enter a vessel. This observation suggests that the fungus may enter the wood by way of the rays.

Inoculation of Walnut Trees with the Fungus from Affected Walnut Branches. Judging from the results of inoculating walnut trees over a period of years, the development of extensive symptoms by the dark-spored fungus depends on several factors, not all of which have been determined adequately. As shown in table 1, symptoms were not obtained when the fungus was inserted into slits in the bark ${ }^{5}$ during January, February, March, or April; but necrosis of bark and wood resulted if inoculations were made in June and July. Much more extensive symptoms were obtained in the Mayette and Franquette varieties than in Concord. Young trees of the first two varieties were killed within 19 to 30 days after being inoculated in July with isolates of the fungus from two localities. Isolates from two orchards in a third locality also proved pathogenic when inoculated into older trees during July.

The sudden wilting of the foliage of inoculated trees resembled, in all respects, that on naturally infected branches. In several cases black spore masses were produced beneath the periderm a few days after the branches wilted, and the fungus was obtained in pure culture from the discolored wood 4 to 8 inches from the point of inoculation.

\footnotetext{
${ }^{5}$ These slits were protected from drying by waxed paper over which adhesive tape was placed.
} 
Characteristics on the Host and in Artificial Media. The fungus grows rapidly at $25^{\circ} \mathrm{C}$ or above on potato-dextrose, oatmeal, and malt-extract agar media, producing dark subsurface mycelium. At first the aerial mycelium

TABLE 1

Results of Inoculating Walnut Trees with Four Isolates of the Fungus FroM WILTED WALNUT BRANCHES

\begin{tabular}{|c|c|c|c|}
\hline \multirow[t]{2}{*}{$\begin{array}{c}\text { Walnut variety, inoculation date, } \\
\text { and orchard } \\
\text { where isolate was obtained }\end{array}$} & \multicolumn{2}{|c|}{$\begin{array}{c}\text { Length of } \\
\text { necrotic areas, } \\
\text { in inches, one } \\
\text { month after } \\
\text { inoculation }\end{array}$} & \multirow[t]{2}{*}{ Remarks } \\
\hline & In bark & In wood & \\
\hline \multicolumn{4}{|l|}{ Concord variety: } \\
\hline \multicolumn{4}{|l|}{ March 13, 1942: } \\
\hline Eyre orchard.. & 0 & 0.1 & Necrotic area in wood buried by new tissue \\
\hline Newman orchard. . & 0 & 0.4 & Necrotic area in wood buried by new tissue \\
\hline \multicolumn{4}{|l|}{ April 10, 1942: } \\
\hline Eyre orchard. & 0 & 0.4 & Necrotic area in wood buried by new tissue \\
\hline Newman orchard.. & 0 & 0.1 & Necrotic area in wood buried by new tissue \\
\hline June 23,1942 , Eyre orchard.. & 2.5 & 3.0 & Necrotic area in bark healed in summer \\
\hline \multicolumn{4}{|l|}{ July 24,1942 : } \\
\hline Eyre orchard. . & 1.7 & 5.2 & Necrotic area in bark healed in summer \\
\hline Newman orchard.. & 2.0 & 6.0 & Necrotic area in bark healed in summer \\
\hline July 3,1943 , Newman orchard. & 3.2 & 4.0 & Sapwood killed $5 \mathrm{~mm}$ deep \\
\hline July 3, 1944, Newman orchard. . & 2.7 & 5.0 & Sapwood killed $3 \mathrm{~mm}$ deep \\
\hline July 24,1945 , Hillman orchard. . & 2.7 & 4.2 & Sapwood killed $5 \mathrm{~mm}$ deep \\
\hline \multicolumn{4}{|l|}{ Mayette variety: } \\
\hline \multicolumn{4}{|l|}{ July 17, 1942: } \\
\hline Eyre orchard. & 4.6 & 9.0 & Sapwood killed $10 \mathrm{~mm}$ deep \\
\hline Newman orchard... & 4.1 & 7.0 & Sapwood killed $12 \mathrm{~mm}$ deep \\
\hline \multicolumn{4}{|l|}{ July 24,1945 : } \\
\hline Hillman orchard. . & 7.3 & 7.0 & Killed 2 young trees \\
\hline Rowland orchard. & 9.0 & 14.0 & Killed 1 young tree \\
\hline July 30,1945 , Rowland orchard. & 12.0 & 15.2 & Killed side branches of 3 trees \\
\hline \multicolumn{4}{|l|}{ Franquette variety: } \\
\hline \multicolumn{4}{|l|}{ July 17,1942 : } \\
\hline Eyre orchard. & 4.3 & 10.0 & One branch 0.5 inch diameter killed \\
\hline Newman orchard. & 6.0 & 10.0 & One branch 1.0 inch diameter killed \\
\hline January 28,1946, Rowland orchard.. & 0 & 0 & Inoculation wounds healed \\
\hline February 28,1946 , Rowland orchard. & 0 & 0 & Inoculation wounds healed \\
\hline April 12, 1946, Rowland orchard... & 0 & 0 & Inoculation wounds healed \\
\hline May 21,1946 , Rowland orchard....... & 0.5 & 0.7 & Necrotic area in sapwood buried by new tissue \\
\hline June 28,1946 , Rowland orchard....... & 1.5 & 2.7 & Healed around margins of necrotic area in bark \\
\hline July 8,1946 Rowland orchard $\ldots \ldots \ldots$ & 5.0 & 7.0 & Killed 2 young trees \\
\hline July 24,1946 , Rowland orchard....... & 6.0 & 7.1 & Killed 3 young trees \\
\hline
\end{tabular}

* Location of orchard from which isolates were obtained: Eyre and Newman orchards at Visalia, Hillman orchard at Biggs, and Rowland orchard at Los Molinos.

is grayish, but later it becomes dark brown to black because numerous dark, profusely branched sporophores ${ }^{\circ}$ are present. Although the formation of spores in culture is difficult to follow in detail, because sporophores break apart if disturbed, the process is believed to be as follows : An aerial hypha arising from the mycelium in the substrate branches several times. Cross-walls

${ }^{6}$ Conidiophore, if one uses this term to designate the entire fruiting structure. However, the stalk which bears the conidia is usually called the conidiophore. This structure is only slightly developed or absent in the fungus being discussed. 
appear (fig. 2, $A$ ), first in the branches, then throughout the entire length of the sporophore. The hyphal segments become rounded, develop heavy walls and a dark brown color. Upon being disturbed, the entire sporophore will now break apart into one-celled and, in a few cases, two-celled segments. These segments (arthrospores) germinate readily when given the proper conditions. On potato-dextrose agar the fruiting structure is usually much longer and more profusely branched than that shown in figure $2, A$.

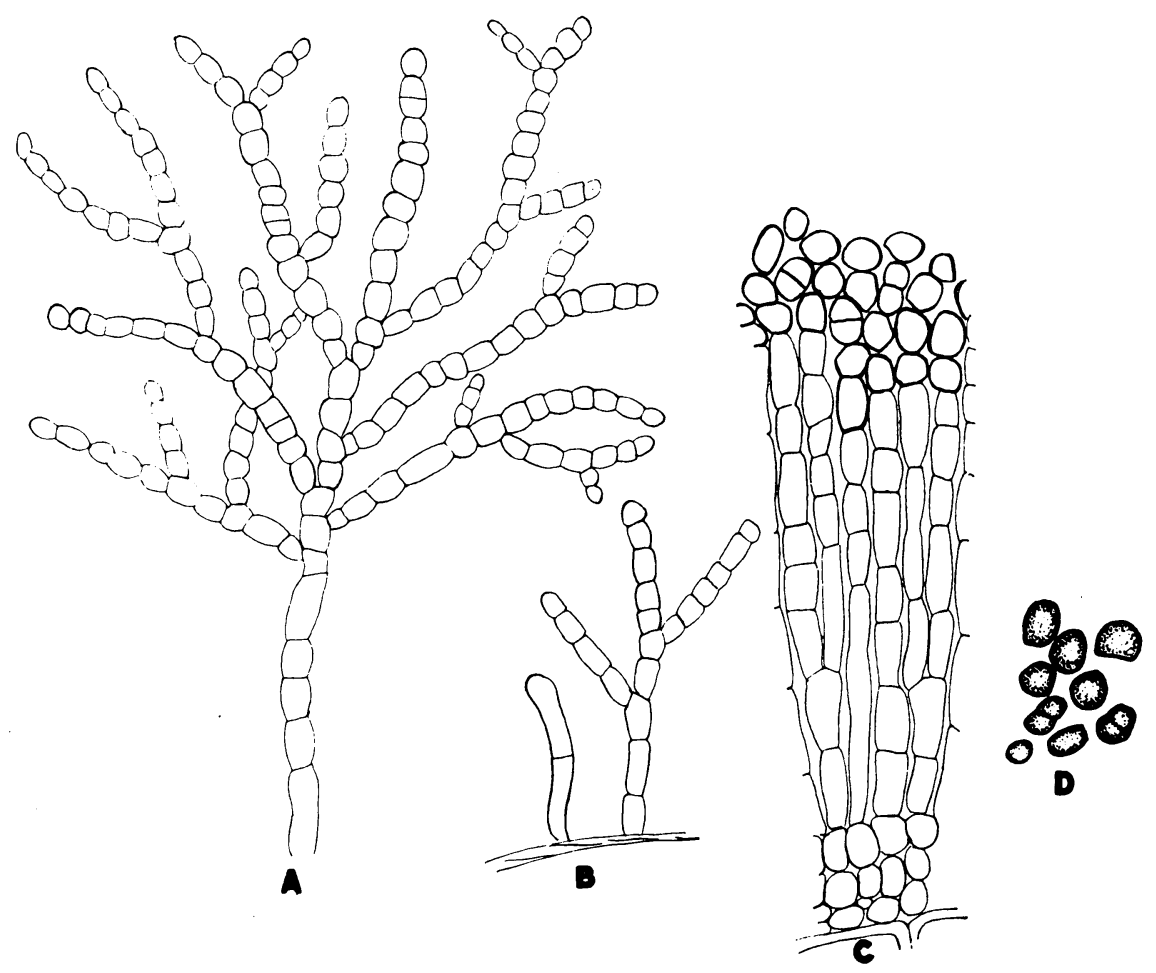

Fig. 2.-A, One of the simpler sporophores produced by the walnut branch-wilt fungus on potato-dextrose agar $(\times 525)$. $B$, Sporophores produced on diseased bark which was kept in a moist-chamber $(\times 400)$. The segments of the entire sporophore fall apart and function as conidia. $C$, Section through sporodochium produced under natural conditions $(\times 600)$. All cells of the upright hyphae arising from the slight hypostroma eventually mature into heavy-walled, dark-colored arthrospores. $D$, Arthrospores of various sizes and shapes from the host $(\times 600)$.

If thin radial sections of diseased bark are washed free of spores and mounted in a moist-cell, there soon develop short branched sporophores like those in figure $2, B$.

The type of fruiting structure shown in figure $2, A$ and $B$, resembles that of a Torula Pers. and would place the fungus in this genus were it not that under natural conditions compact sporogenous bodies are commonly produced on the host. Upon examining the sooty deposit beneath the loosened periderm of branches, one often finds the spores in an almost unbroken layer, individual spores being separate from each other. Beneath this spore layer 
are a few segments, lighter colored and thinner walled than the spores. In other areas, however, the spore masses occur in clumps, at the base of which are a few thin-walled segments. These clumps are individual fruiting structures that have almost completely broken up into arthrospores. If the periderm of recently wilted branches is removed carefully, immature fruiting structures often can be found. Plate $3, D$ and $F$, shows mature and immature structures, $1 \mathrm{~mm}$ or more in diameter, which were produced on a small walnut branch. When not too numerous these often raise the periderm into small pimples (plate $4, A$ ). Plate $3, A$, is a longitudinal radial section through the bark cortex, and through a partly mature fruiting body. At this stage the structure (fig. $2, C$ ) is composed of a few thin-walled basal cells (hypo-

TABLE 2

Pathogenicity of Isolates from Persian Walnut, European Chestnut, and Grapefruit to Young Trees of the Franquette Variety of Persian Walnut

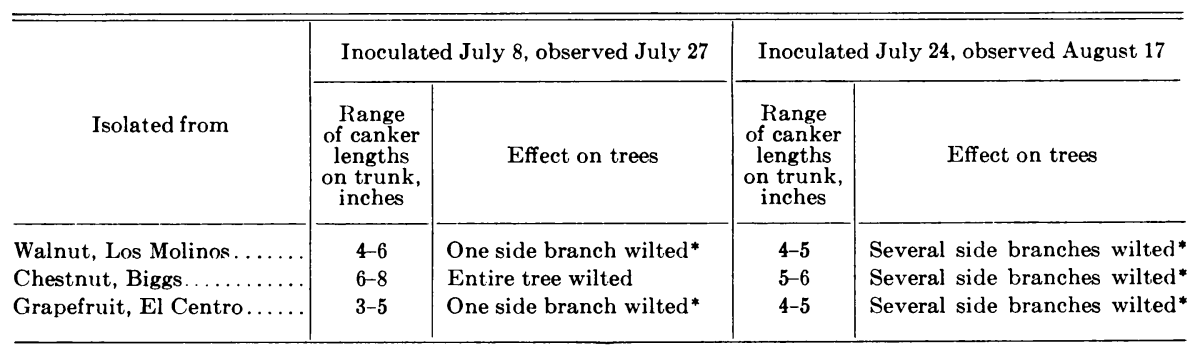

* Certain trees later died.

stroma) from which arise parallel hyphae in a compact mass. The hyphae are septate throughout their length, and some of the end segments have become thick-walled, dark, and separate from each other. Apparently segmentation of hyphae progresses downward from the ends (basipetally), until eventually the entire body, except the hypostroma, crumbles into a mass of separate spores. When numerous, the crumbled fruiting structures produce an unbroken layer over a considerable area of cortex.

On cornmeal agar $^{7}$ and inoculated steam-sterilized walnut twigs, the toruloid type of fruiting structure is sparse ; instead, an elaborate stroma develops (plate $3, B$ ). The arthrospores are produced by segmentation of hyphae arising from the surface of this body.

In one culture series on cornmeal agar, 1 to 3 spheroid cavities developed in certain of the fruiting structures. A number of the cavities were filled with spindle-shaped to ovoid bodies resembling pycnidiospores. Unfortunately, none of the bodies matured, and none of the pycnidiumlike cavities has since been observed in single-spore cultures. Some time later, welldeveloped stromata containing flask-shaped cavities with ostioles were found under and among the arthrospores of the wilt fungus on one small walnut twig. Though most of the cavities were empty, a few contained two or three ovoid, hyaline spores, which were produced on short stalks arising from the

${ }^{7}$ Shear's formula: 20 grams of cornmeal per liter of water, heated in water bath at $58^{\circ} \mathrm{C}$ for 1 hour and filtered. To filtrate was added 15 grams per liter of agar. 
sides of the cavity. Because these spores were so scarce, they could not be successfully segregated from the numerous arthrospores surrounding the stroma. Careful search has not revealed any further cases of this sort; and since a Dothiorella species, which produces a similar structure, is not uncommon on dead walnut twigs, possibly the stromata may have been those of such a fungus. Decisions on the significance of these observations must therefore be postponed.

A few ascomycetes found growing on wilt-infected walnut limbs have not proved to be the sexual stage of the branch-wilt fungus. Because no perfect stage has been found and the status of the pycnidial stage is doubtful, the branch-wilt fungus must be classified on the basis of its conidial fruiting structure.

The first question concerns the nature of this fruiting structure. Both on the host and in young cornmeal-agar cultures, the fertile hyphae arise from what appears to be a loosely packed mass of mycelium, though the elements of the mycelium may eventually lose their identity and, in the structures on agar, sometimes form a compact hypostroma (plate $3, B$ ). According to a definition by Clements and Shear (1931, p. 196) this structure is a sporodochium, which "is to be regarded as a compacting of hyphae and conidiophores rather than a new development from a reduced fruiting-body with short or obsolescent basidia."

Before further identification is attempted, the results of comparing the fungi from the various hosts must be given.

\section{COMPARISONS OF ISOLATES FROM CHESTNUT, CITRUS, AND WALNUT}

Upon being shown the walnut pathogen, H. S. Fawcett of the University Citrus Experiment Station at Riverside recognized it as resembling a fungus he obtained in 1923 from frost-injured orange and grapefruit trees in Tulare County, California. According to him (Fawcett, 1936), the fungus appeared to be Torula dimidiata Penz. His description of the black powdery layer of spores under the branch periderm is reminiscent of the manner in which the walnut pathogen sporulates. Mr. Fawcett kindly furnished the writer with his 1923 specimens, and later sent cultures and specimens obtained from grapefruit trees at El Centro, California, in 1945. As reported earlier in this paper, the writer found a similar fungus on wilted lemon branches in Tulare County in August, 1946. Black powdery layers of spores occurred at various places beneath the periderm of affected branches, and the fungus was readily isolated from the wood of recently wilted branches.

In the following sections are reported comparative studies of the isolates obtained from grapefruit at El Centro, chestnut at Biggs, and Persian walnut at Los Molinos. The black-walnut isolate was obtained too late to be included in certain of these studies.

Pathogenicity to Persian Walnut. In the summer of 1946 three series of inoculations were made on young Franquette (Lattin strain) walnut trees growing at Davis. The first, June 6 , resulted in the formation of small cankers ( 1 to 2 inches long) by all three isolates, those produced by the walnut and chestnut isolates being somewhat longer than those from the grapefruit. In 
the next two series of inoculations (made in July), however, extensive symptoms were produced by all three isolates (table 2 ). On the whole, the chestnut isolate appeared to be the most active, completely involving the bark and wood for several inches around the point of inoculation and killing the young trees within 19 days. Certain trees, however, were later killed by the walnut

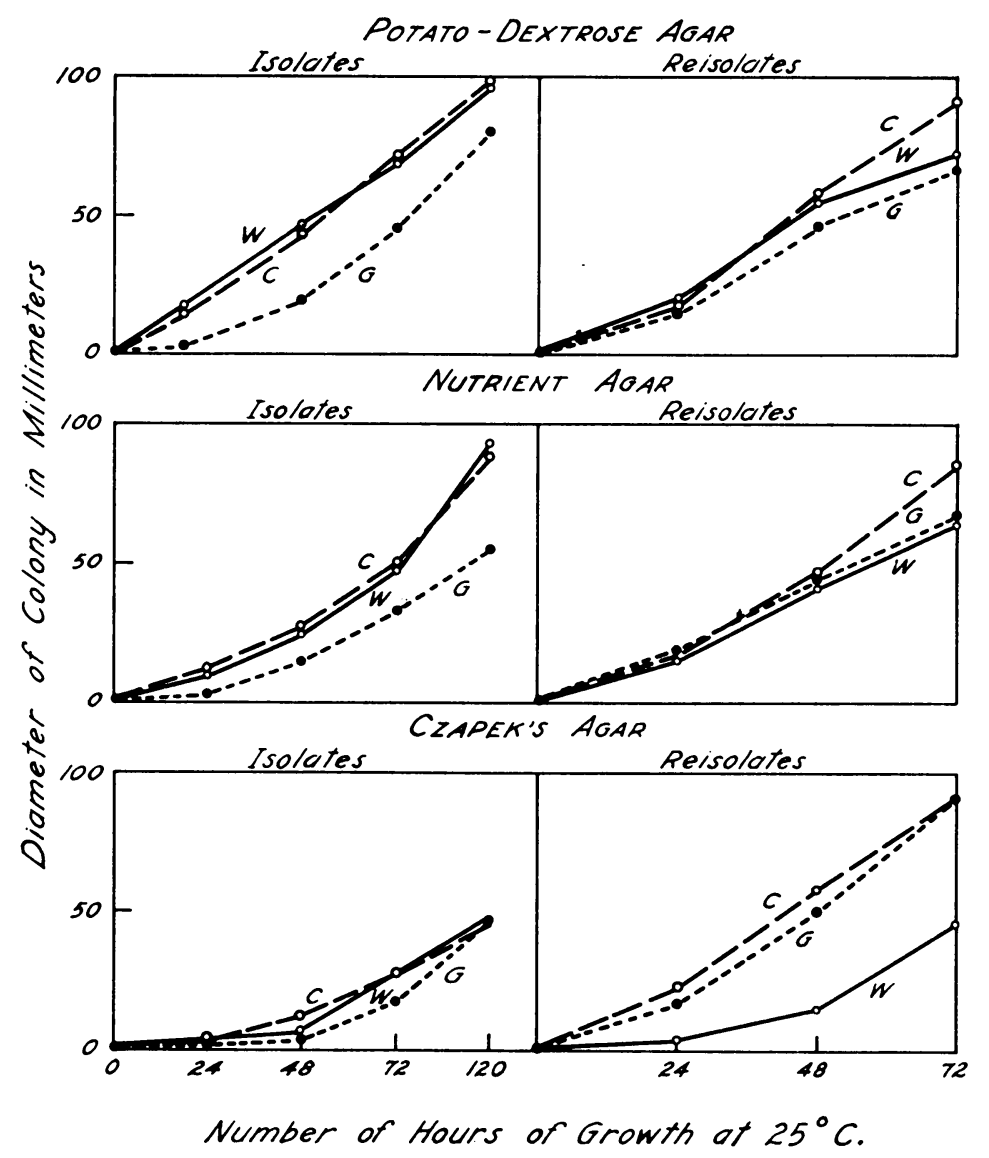

Fig. 3.- Rate of growth of the $(W)$ walnut, $(C)$ chestnut, and $(G)$ grapefruit isolates on three solid media.

and grapefruit isolates. Judging from these tests, there seemed to be little doubt that the grapefruit and chestnut isolates were able to cause symptoms identical with those produced by the walnut pathogen. All three isolates were recovered from the wood of inoculated trees in areas 4 to 6 inches from the point of inoculation. Single-spore cultures of the reisolates were kept for comparison with the original isolates. These comparisons are described later.

Growth on Various Media. The three isolates were grown on several types of solid media. The principal difference in growth on most media was the tendency for the grapefruit fungus from El Centro to develop the shorter 
and sparser aerial hyphae. All produce the toruloid type of conidiophores on potato-dextrose, nutrient, malt-extract, and oatmeal agars.

Of single-spore cultures of the original isolates, the one from grapefruit consistently grew slowest on potato-dextrose, nutrient, and Czapek agars (fig. 3). This difference was less noticeable, however, after passage of the isolates through walnut trees (fig. 3, reisolates); apparently, the growth rate was modified by the host.

Size and Shape of Arthrospores. Mature arthrospores of all three isolates varied widely in size and shape. The shape of arthrospores from walnut, chestnut, grapefruit, and lemon bark was similar. The color was the same in hue, but slightly different in shade, those from citrus hosts being lighter. On cornmeal agar the grapefruit and lemon isolates produced spores that were preponderantly spheroidal, whereas on this medium the isolates from chestnut and walnut produced spores more irregular in shape, some being spheroidal, others ovoidal or roughly cylindrical. It was learned later, however, that among single-spore isolates of the fungus from Persian walnut, some produced a greater number of spheroidal spores than others. Since these differences in spore characteristics are associated with differences in the structure of the sporodochia, the subject is discussed under another heading.

To obtain a single expression for size, the maximum and minimum dimensions of each spore were determined. These values, averaged as the mean diameter, are as follows :

Isolate

Walnut. . .

Chestnut.

Grapefruit.

$\begin{array}{cc}\text { Mean diameter of spores, in microns } \\ \begin{array}{c}\text { From } \\ \text { diseased bark }\end{array} & \begin{array}{c}\text { From } \\ \text { potato-dextrose agar }\end{array} \\ 5.5 & 5.1 \\ 5.1 & 5.5 \\ 5.2 & 4.5\end{array}$

Though the size of spores from the host did not differ greatly among the three isolates, spores of the grapefruit isolate taken from potato-dextrose agar were somewhat smaller than those of the other two. When, moreover, frequency curves were plotted for the average mean diameter of 100 spores of each isolate, spores of the walnut and chestnut isolates were found to be in the same modal class, whereas those of the grapefruit isolate were one class lower. This held true for spores from the host as well as those from culture. Apparently, therefore, the grapefruit isolate tends to produce the smallest spores.

Temperature Requirements. The walnut pathogen, in several tests, required fairly high temperature for growth. At $16^{\circ} \mathrm{C}$ and below, it grew slowly ; but the rate increased rapidly with increases in temperature above $16^{\circ}$, the most rapid mycelial growth occurring between $30^{\circ}$ and $33^{\circ}$. Above $33^{\circ}$, however, growth was slower.

According to the data in figure 4, all three isolates responded to temperature in about the same way, although here, as in tests reported in the previous section, at all temperatures the grapefruit isolate grew somewhat more slowly than the other two.

Production of Sporodochia. On grapefruit bark collected by H. S. Fawcett and on lemon bark collected by the writer, the spores frequently occurred in clumps scattered over the surface of the cortex. These clumps were found 
to contain varying amounts of stromatic tissue with an overlying layer of spores. These spores had become separated from one another, and their original arrangement lost. Since immature fruiting bodies were not found on lemon or grapefruit, as they were on walnut, the manner in which the spores were formed was not determined on these hosts. The mature fruiting structures on citrus, chestnut, and walnut, were similar in all respects. Plate $4, B$, $C$, and $D$ (page 436), shows the nature of the spore layers on these hosts.

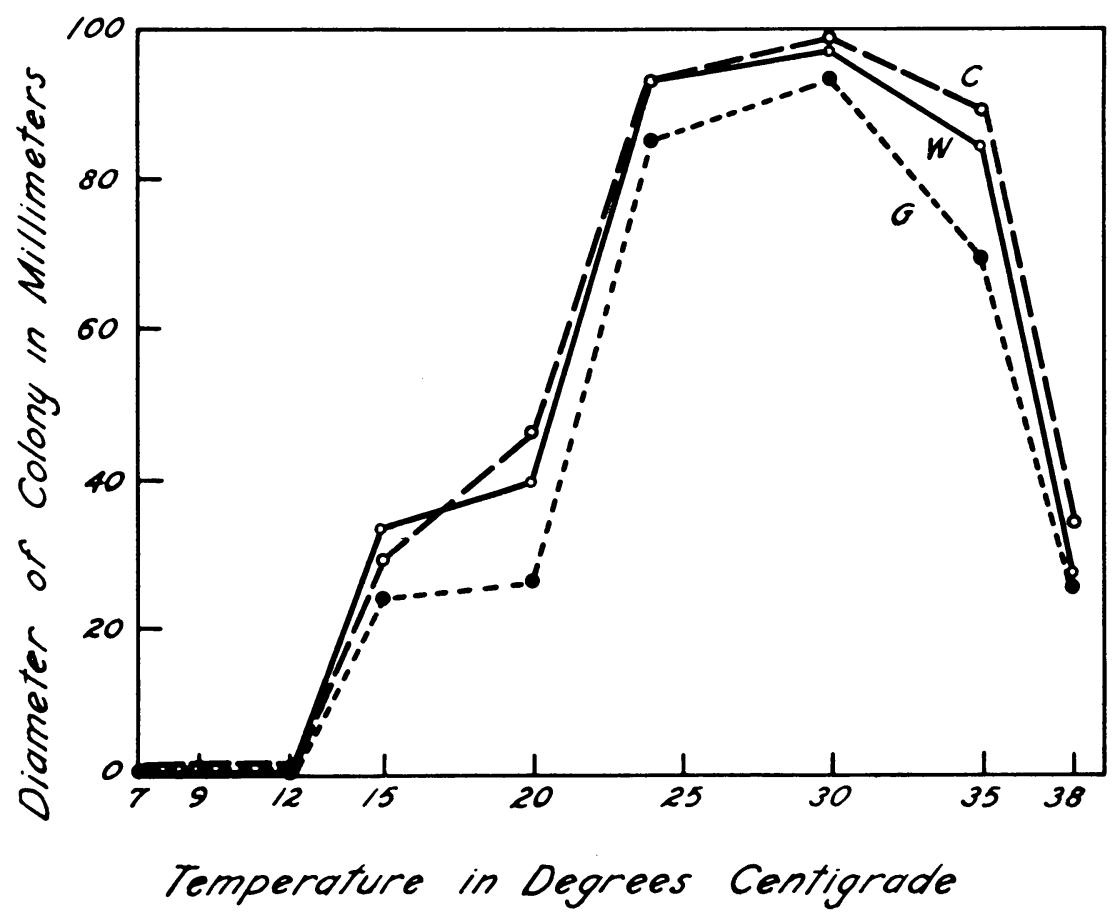

Fig. 4.- Relation of temperature to mycelial growth of the $\left(W^{r}\right)$ walnut, $(C)$ ehestnut, and $(G)$ grapefruit isolates.

Sporodochia produced by the Persian walnut, chestnut, and grapefruit isolates on inoculated steam-sterilized walnut twigs are pictured in plate $3, \boldsymbol{E}$ (page 435).

As noted earlier, isolates from Persian walnut produced more or less densely packed sporodochia on cornmeal agar. In some cases (plate $3, B$ ) these bodies contained fairly large amounts of stromatic tissue, from which arose the sporogenous hyphae. In other eases, however, the individual hyphal elements of the sporodochia retained their identity and were grouped together in a loosely compacted body with little or no hypostroma.

For comparing sporodochial production, the walnut, chestnut, and grapefruit isolates, and the reisolates, mentioned in foregoing tests, together with six other single-spore isolates from Persian walnut, one from black walnut, and one from lemon, were grown on cornmeal agar at $25^{\circ} \mathrm{C}$. Though differences in the rate of growth and in production of sporodochia occurred, these 
features varied no more between the isolates from the three hosts than between those from Persian walnut. The grapefruit and lemon isolates produced spores that were preponderantly spheroidal, a fact mentioned earlier. These isolates also developed sporodochia that were more compact and contained greater amounts of hypostroma than sporodochia of certain walnut isolates. On the other hand, two of the walnut isolates produced compact sporodochia, though few in number. The grapefruit reisolate differed from all others in producing no spores on this medium, though it sporulated freely on potato-dextrose agar. Apparently, therefore, the rather wide differences in the structure of the sporodochium and shape of spores which occurred on cornmeal agar did not serve to distinguish the grapefruit isolate from the walnut and chestnut isolates.

\section{IDENTITY OF THE WALNUT PATHOGEN}

Judging from the foregoing comparisons, the fungus from citrus, though differing from the walnut pathogen in size of spores and in abundance and length of aerial growth on solid media, is similar in other characteristics; so far as these studies go, there seems to be no reason for considering it a separate species. Moreover, there appeared to be no major difference between the chestnut and the walnut isolates.

The writer is uncertain how a reclassification of the citrus fungus should affect the status of Torula dimidiata. Unquestionably, the fungus from citrus, chestnut, and walnut resembles Penzig's organism, producing under some conditions single toruloid conidiophores; but, as we have seen, sporodochia are produced on the host. The sporodochium, except for the thin hypostroma, breaks apart into a mass of arthrospores. The bark periderm must contribute to this process, for at most the sporodochium is a loosely compacted structure and, being compressed between the periderm and cortex, is crushed into a flattened disorganized layer as the conidial chains mature. From this mass one might conclude that the spores had been produced on numerous separate conidiophores, or at most on small tufts of conidiophores. One might obtain support of this conclusion by washing the old spores from the cortex and keeping the bark in a moist chamber. Under such conditions, as we have seen (fig. $2, B)$, short toruloid sporophores develop.

Penzig (Penzig, 1887) reported his fungus as producing irregular, dark brown, velvety tufts on lemon bark. The arthrospores are said to measure 4 to $5 \mu$-slightly (but possibly not significantly) smaller than those of Fawcett's organism. Except in this and in other small details, Fawcett's organism fits Penzig's description, provided the sporophores that arise from the periderm-free cortex of bark kept under moist conditions are considered to be the typical fruiting structure. That this typical structure is a sporodochium, not a single sporophore, can hardly be disputed if early stages of fructification are studied. Although Penzig possibly dealt with the fungus described herein, so that his may have been the first description, this description is very inadequate. Since it is possible that he had another fungus, the writer is not willing at this time to alter the status of Torula dimidiata.

The possession of sessile sporodochia, dark brown mycelium, and conidia of the same color would place the branch-wilt fungus in the family Tubercu- 
lariaceae, section Dematieae. Though the arthrospores are sometimes twocelled, because an occasional septum fails to reach the stage where separation occurs, the great majority of these bodies are one-celled. Apparently the sporodochium is without spines or setae, and the conidiophore is much reduced, if not absent. The arthrospores are smooth and, being formed by the segmentation of hyphae, are of course catenulate. These characteristics apparently place the fungus in the genus Exosporina Oudemans, whose form species is Exosporina laricis Oud.

According to Oudemans (Oudemans, 1904), Corda and Saccardo had described as Trimmatostroma salicis, a similar fungus on willow. Since, however, the genus Trimmatostroma as constituted by Corda produces multicellular conidia, Oudemans erected the genus Exosporina, which he described as including exposed or endogenous fungi with no "stroma" (hypostroma) or with this structure slightly developed. Conidia are arranged in chains, separating individually, homomorphic, continuous, and colored. Concerning $E$. laricis he says that the fruiting structures are amphigenous (presumably with regard to their occurrence on both sides of larch needles), exposed, punctiform, and black. The rather long "stipitate" chains are closely condensed into a convex "placenta." The conidia are at first angular, then globular, ferruginous, continuous, 5 to $6 \times 5 \mu$, and separating individually.

The branch-wilt fungus resembles the type species in shape of conidia, which are first angular, then globular; and in the manner in which the conidial chains separate into segments. In size the conidia of the branch-wilt fungus vary somewhat more than those of Exosporina laricis, the former in one series of measurements being 4.2 to $8.3 \mu$ long by 3.3 to $8.3 \mu$ wide (average $6.1 \times 5.2 \mu$ ). Judging from Oudemans' illustrations, which are somewhat diagrammatical, the two fungi differ with respect to the hypostroma and the branching of the sporodochial chains. Whereas Oudemans shows $E$. laricis without hypostroma and with nonbranched conidial chains, the sporodochium of the branch-wilt fungus possesses a definite hypostroma and the conidial chains are not infrequently branched. Apparently, moreover, E. laricis is not found on the woody parts of the host but is restricted to the needles, whereas the branch-wilt fungus grows extensively through the wood and bark tissues. These contrasting features would seem to indicate the two fungi though similar are not identical.

Newodowski (1912) reported Exosporina mali Newodowski as pathogenic to young apple branches in Tiflis. The conidia of this fungus are 11.0 to $25.0 \mu$ by 6.0 to $8.5 \mu$, much larger than those of the branch-wilt pathogen. The terminal spores on the conidial chains of $E$. mali possess apical protuberances, a feature not found on spores of the branch-wilt fungus.

Hendersonula toruloidea Nattrass, found on peach twigs in Egypt and citrus twigs in Cyprus (Nattrass, 1933), produces toruloid conidiophores resembling to some extent those developed by the branch-wilt pathogen on potato-dextrose agar. On the host the conidiophores of $H$. toruloidea are said to arise from a thin layer of fungal tissue which later develops into a stroma containing pycnidia at different levels. The pyenidiospores, so long as they remain inside the pycnidium, are colorless and nonseptate, but upon being extruded develop two septa and a dark-colored central spore. In 1931 A. J. 
Olson (Fawcett, 1936) found a similar fungus on frost-injured citrus branches near Hamilton City, Glenn County, and later proved this fungus capable of producing wood rot and fruit rot of oranges and lemons. In a recent letter to the writer, Mr. Fawcett says that he noted similarities between this fungus and the fungus he regarded as Torula dimidiata, but since he had no cultures of the latter was unable to compare the two.

The writer found no pycnidia associated with the branch-wilt fungus on citrus. As noted earlier, stromata containing pycnidia and a few pycnidiospores were present on one small walnut branch among the sporodochial stage of the branch-wilt fungus, but no cultures were obtained from these spores. The pycnidia, however, were borne at approximately the same level, and all pycnidiospores seen, whether inside or outside the pycnidium, were hyaline. Judging from these two features, therefore, the stromata resembled those of a Dothiorella more closely than they did those of Hendersonula toruloidea.

Apparently, therefore, Torula dimidiata, Hendersonula toruloidea, and the fungus described here are similar in certain morphological features. $H$. toruloidea and the branch-wilt fungus, moreover, possess similar temperature requirements. On the basis of the available information, however, one is not justified in regarding them as identical.

The name Exosporina fawcetti n. sp. is proposed for the fungus on Persian walnut, European chestnut, and citrus.

Exosporina fawcetti $\mathrm{n}$. sp. A brown to sooty layer of spores develops beneath the periderm of diseased branches, causing this layer to separate from the underlying cortex. Numerous pulvinate, sessile, dark sporodochia up to $400 \mu$ in diameter and $150 \mu$ high develop over surface of the cortex. Sporodochium consists of compact, parallel, occasionally branched, chains of conidia arising from a slight hypostroma. Conidia (arthrospores) in chains mature basipetally, separate readily, are 1-celled (rarely 2- to 3-celled), globoid to slightly angular, dark brown, variable in size-3-8 $\mu$ (averaging $5.5 \mu$ ); the mycelium is dark brown. Aerial hyphae adjacent to sporodochia, torulose, dark brown, separating into great numbers of cells or fragments.

Habitat: On branches of Persian walnut, Juglans regia; European chestnut, Castanea sativa; lemon, Citrus limonia ; grapefruit, C. grandis; and orange, C. sinensis, in California. Type specimens of the fungus deposited in the Mycological Collections of the Division of Botany, University of California, Berkeley. Cotype specimens in the Mycological Herbarium of the United States Department of Agriculture, Beltsville, Maryland.

Exosporina fawcetti $\mathrm{n}$. sp.: Stratum brunneum vel usque fuligeneum sub peridermio evolvet, efficiens ut peridermium de cortice secedat. Numerosa sporodochia pulvinata, sessilia, fusca usque ad $400 \mu$ diametro et $150 \mu$ altitudine supra corticem evolvent. Sporodochium constat ex conidiorum catenis parallelis, de hypostromate parum evoluto surgentibus, aliquando ramificatis. Catenae conidiorum basipetaliter maturescunt, fragmentis facile secedentibus. Sunt conidia continua, raro duarum vel trium cellularum, globosa vel leviter angulata, fusca, magnitudine varia, 3-8 $\mu(5.5 \mu)$; mycelio fusco; hyphis adfinibus sporodochiis torulosis, fuscis, ad numerosa segmenta secedentibus.

Habitat in ramulis juglandis regiae, castaneae sativae, citri limoniae, eitri grandis et eitri sinensis, in California.

\section{DISCUSSION}

Certain relations apparently exist between the incidence of the disease and one or more environmental factors. The first relation concerns the occurrence of branch wilt in all parts of the interior valleys and in adjacent foothill districts where summer temperatures are high. In those places, the malady occurs even where there are few Persian walnut trees. On the other 
hand, branch wilt, in a severe form at least, is not found among the extensive plantings of susceptible varieties in coastal districts, where summer temperatures are much lower than in the interior. Since the height of disease activity comes in the summer, and since the fungus grows best at comparatively high temperatures, a correlation seems to exist between temperature and disease severity.

The second relation concerns the high degree of selectivity which branch wilt exhibits in its attack on susceptible hosts. A correlation between severity of infection and vigor of the trees has been cited. It is not apparent, however, whether the pathogen finds conditions for development more favorable in weakened than in normal branches or whether the sparsity of foliage that accompanies low vigor contributes to sunburning of the branches and consequently to an increase in opportunities for infection.

Branch wilt shows a selectivity with regard to trees of different ages : the incidence of infection is noticeably low in solid plantings of young trees. Young replants in older orchards where branch wilt is present, on the other hand, sometimes contract the disease severely. Judging from the inoculation tests, young trees are not noticeably resistant to the development of branch wilt, once the fungus gains entrance to the bark. One might suppose, therefore, that young orchards are free of the disease only because the trees are farther away from infection centers. Since, however, the fungus seems ideally adapted to wind dissemination because of an abundant supply of dry powdery spores, the freedom of young orchards from wilt probably is due to some other cause or causes, such as freedom from bark injuries and sunburning.

The earliest cases of walnut branch wilt were found in Tulare County, where the disease has since gained its greatest headway. There is evidence, however, that it appeared about the same time in certain parts of the Sacramento Valley. Here, too, it increased greatly in subsequent years. These facts might indicate that the disease either is of recent origin, has been introduced from another region, or has spread to Persian walnuts from another host. Nothing, however, has been learned that would support the theory of introduction, and little to suggest that the disease spread from another host. Though the black walnuts would be the first host suspected, search has revealed few black-walnut branches with the fungus. The chestnut is excluded as a likely source of infection because no chestnut trees are grown in districts where the disease has become most prevalent. We know, of course, that the fungus occurred on citrus near Porterville twenty-three years ago, and is present near there today in at least one lemon grove. The Porterville district is about 20 miles south of the center of walnut-wilt infection in Tulare County. Though few large walnut plantings occur near Porterville or in areas immediately north, one large planting is located about 5 miles west. In this orchard, wilt developed on a few branches, apparently for the first time, in 1946. Moreover, except in a small orchard at Exeter, the disease is of little consequence a few miles south of the principal center of walnut infection. which is about 5 miles west of Visalia. These circumstances hardly suggest that citrus was the host from which the fungus spread to walnut. More evidence is needed before conclusions can be reached on the origin of this disease. 


\section{SUMMARY}

A disease affecting Persian walnut trees, Juglans regia, and manifested as a sudden wilting of the leaves on certain branches, is described. The bark and wood of affected branches are dead and discolored. A dense layer of fungus spores develops between the cortex and periderm of the branch. Large areas of the latter structure loosen and slough away.

Franquette and Mayette are the varieties chiefly affected by branch wilt, though the Payne, Eureka, Meylan, Blackmer, and Bijou are also attacked. The Concord appears to possess some resistance.

A few branches of northern California black walnut, Juglans hindsii, were found with the black spore deposit; but noticeable wilting of the branches was not found extensively in this species nor in J. californica. European chestnut, Castanea sativa, is attacked by the fungus, the wilting of branches being similar to that in Persian walnut. Wilting of the branches of lemon, Citrus limonia, was observed in one orchard in Tulare County. A similar disease was found on grapefruit and oranges in that county in 1923 by H. S. Fawcett, who reported that the fungus present resembled Torula dimidiata Penz. He also found it on grapefruit near El Centro, Imperial County, in 1945.

Branch wilt is found in walnut trees throughout the Sacramento and San Joaquin valleys and adjacent foothill areas, but has not been reported from the central coastal districts, nor from the principal walnut regions in southern California.

Unthrifty trees are noticeably more subject to wilt than vigorous ones. Trees affected by crown rot or armillaria root rot were shown to suffer more than normal trees.

Branches with bark injured by exposure to the sun are commonly attacked.

Young walnut trees, except replants in mature orchards, are less subject to branch wilt than older trees.

The dark-spored fungus that produces the black layer of spores beneath the branch periderm was found in the wood of a majority of recently wilted branches. Inoculated into Persian walnut trees, this fungus produced extensive cankers that girdled and killed the branches.

On many cultural media the pathogen produces numerous branched sporophores arising singly or in small groups from the substrate. As the sporophores mature they become septate throughout their length, the segments developing thick walls and a dark brown color. At this stage the segments easily separate into one-celled bodies (arthrospores), which will germinate under proper conditions. Under natural conditions on the host, however, sessile pulvinate sporodochia are produced. The spores are produced by a basipetally progressive segmentation of closely packed, parallel hyphae arising from a slight hypostroma. There was no conclusive evidence that the fungus produces other spore forms.

Although the type of fruiting structure produced in most media would place the fungus in the genus Torula Persoon, the development of sporodochia would assign it to the genus Exosporina Oudemans.

So far as the morphological and cultural characteristies were studied, the fungus from diseased grapefruit branches differed only in minor characters 
from the walnut pathogen, and the fungus from chestnut not at all. The grapefruit and chestnut isolates, moreover, produced symptoms in Persian walnut similar in all respects to those produced by the walnut pathogen. The fungus from citrus is therefore regarded as identical with that from chestnut and walnut. The name Exosporina fawcettin. sp. is proposed.

\section{LITERATURE CITED}

Agricultural Adjustment Administration.

1936. California fruit and nut acreage survey. U. S. Dept. Agr. Statistical Pub. 1: 1-176.

Clements, F. E., and C. L. Shear.

1931. The genera of fungi. 496 p. H. W. Wilson Co., New York, N. Y.

FAWCETT, H. S.

1936. Citrus diseases and their control. 656 p. McGraw-Hill Book Company, New York, N. Y.

NATtRASS, R. M.

1933. A new species of Hendersonula (H. toruloidea) on deciduous trees in Egypt. British Myc. Soc. Trans. 18: 189-98.

Newodowski, G.

1912. Mycoflorae Caucasicae movitates. Tiflis Jard. Bot. Viestnik (Monit.) 21: 13-18.

Oudemans, C. A. J. A.

1904. Exosporina laricis, a new microscopic fungus occurring on the larch and very injurious to this tree. $\mathrm{K}$. Akad. van Wetensch. te Amsterdam [Roy. Acad. Amsterdam ] Proc. 6: 498-501. (English translation from: Verslag van de Gewone Vergadering Wis-en Natuurkundige Afdeeling van Zaterdag. 12: Jan. 3, 1904.)

Penzig, Ottone.

1887. Studi botanici sugli agrumi e sulle piante affini. 590 p. Memoria Premiata dal R. Ministero dell'Agricoltura (Dagli Annali di Agricoltura 1887). Tipografia Eredi Botta, Rome, Italy.

WILSON, E. E.

1945. A wilt disease of Persian walnuts in California. Plant Dis. Reptr. 29 : 614-15.

1946. The branch wilt of walnut trees. Diamond Walnut News 28: 7 . 


\section{PLATES}




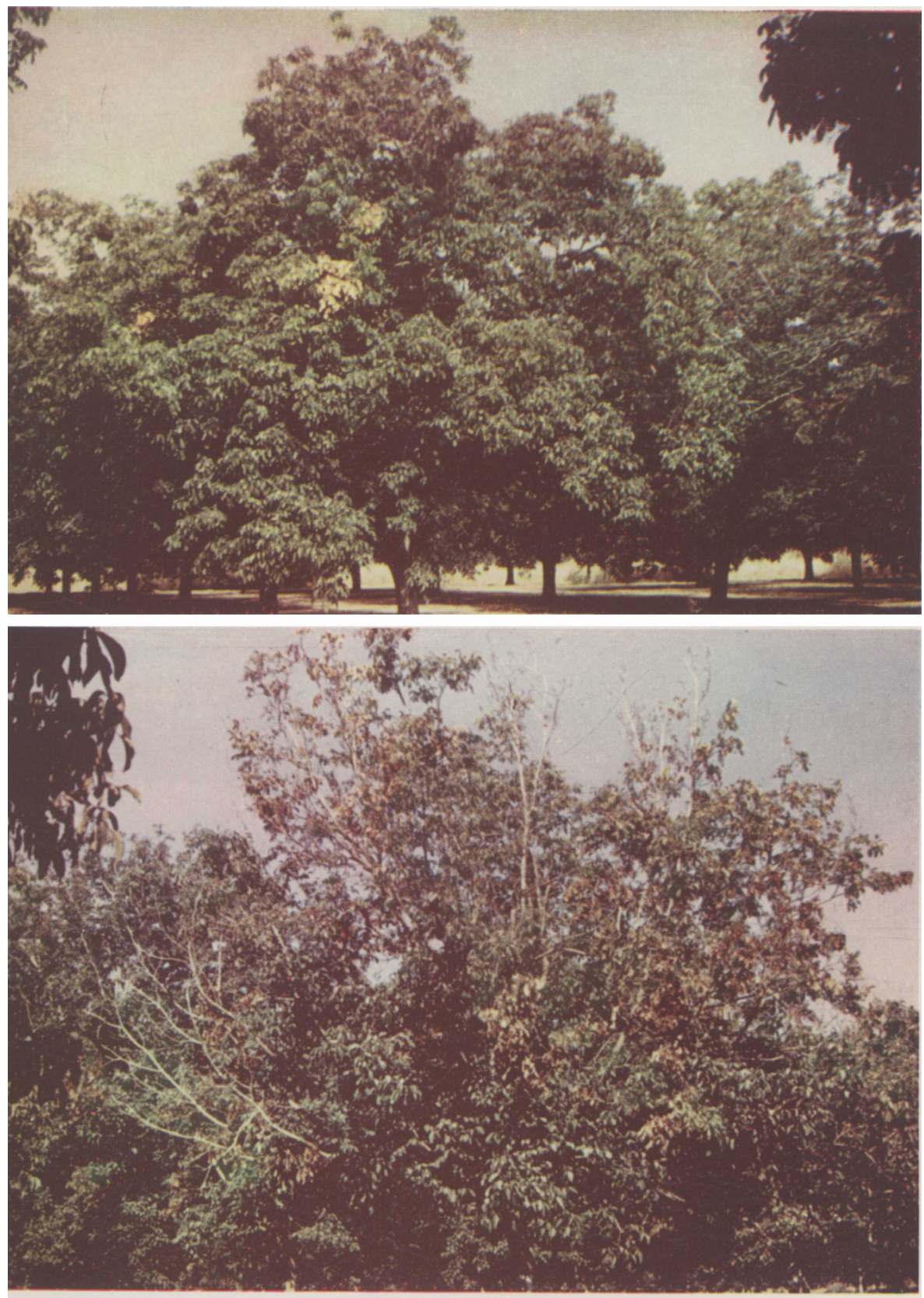

Plate 1.-Persian walnut trees affected by branch wilt. (Photographed by E. F. Serr.) 

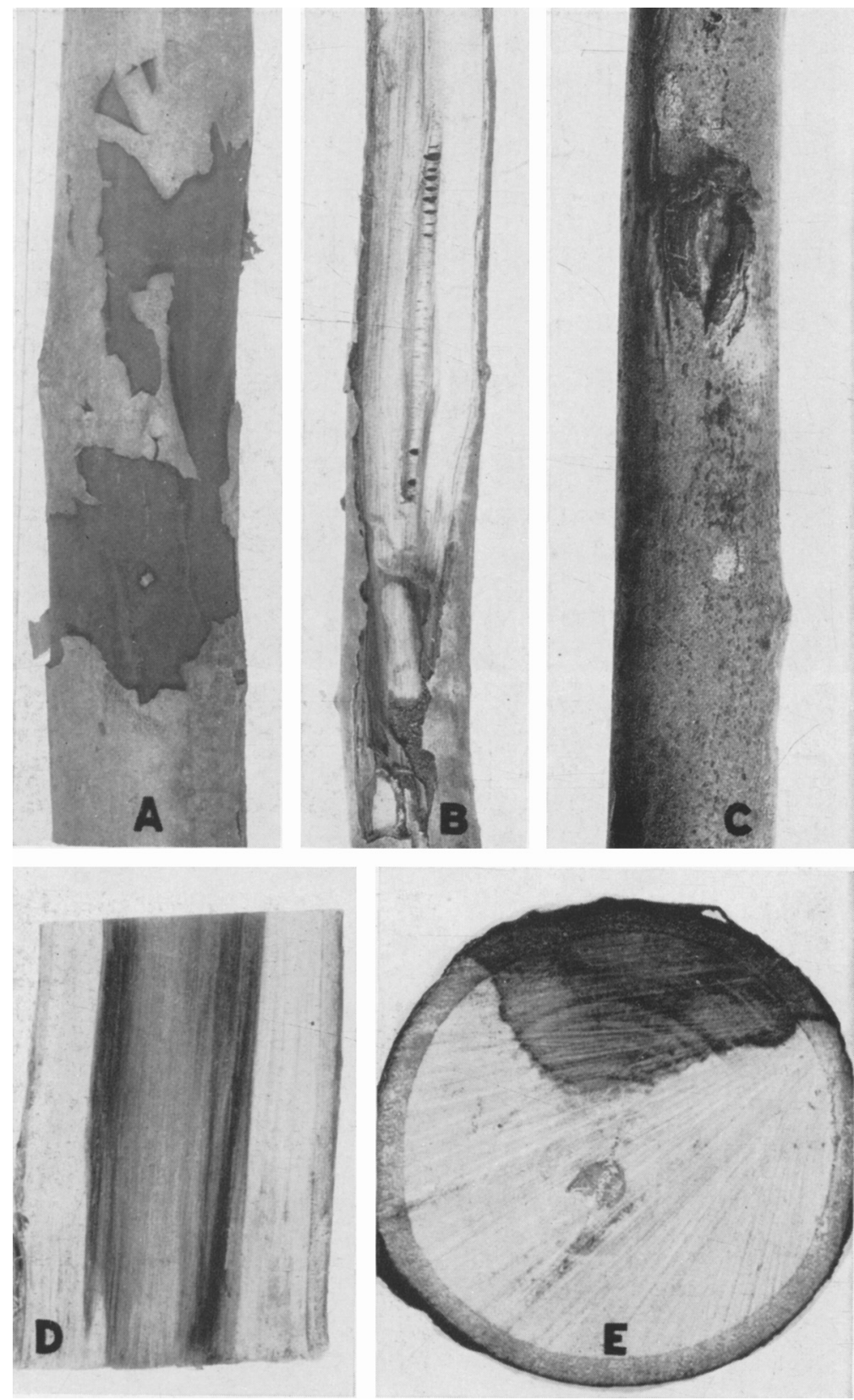

Plate 2.-The bark and wood of wilt-affected walnut branches: $A$, periderm sloughed away exposing the cortex, which is covered by a sooty layer of fungus spores; $B$, grayish discoloration of the wood in a branch recently killed by branch wilt; $C$, a wound, probably made by a harvesting hook, surrounded by a branch-wilt canker; $D$, black discoloration extending through the heartwood of a diseased limb; $E$, a diseased area extending into the wood from one side of a branch. 

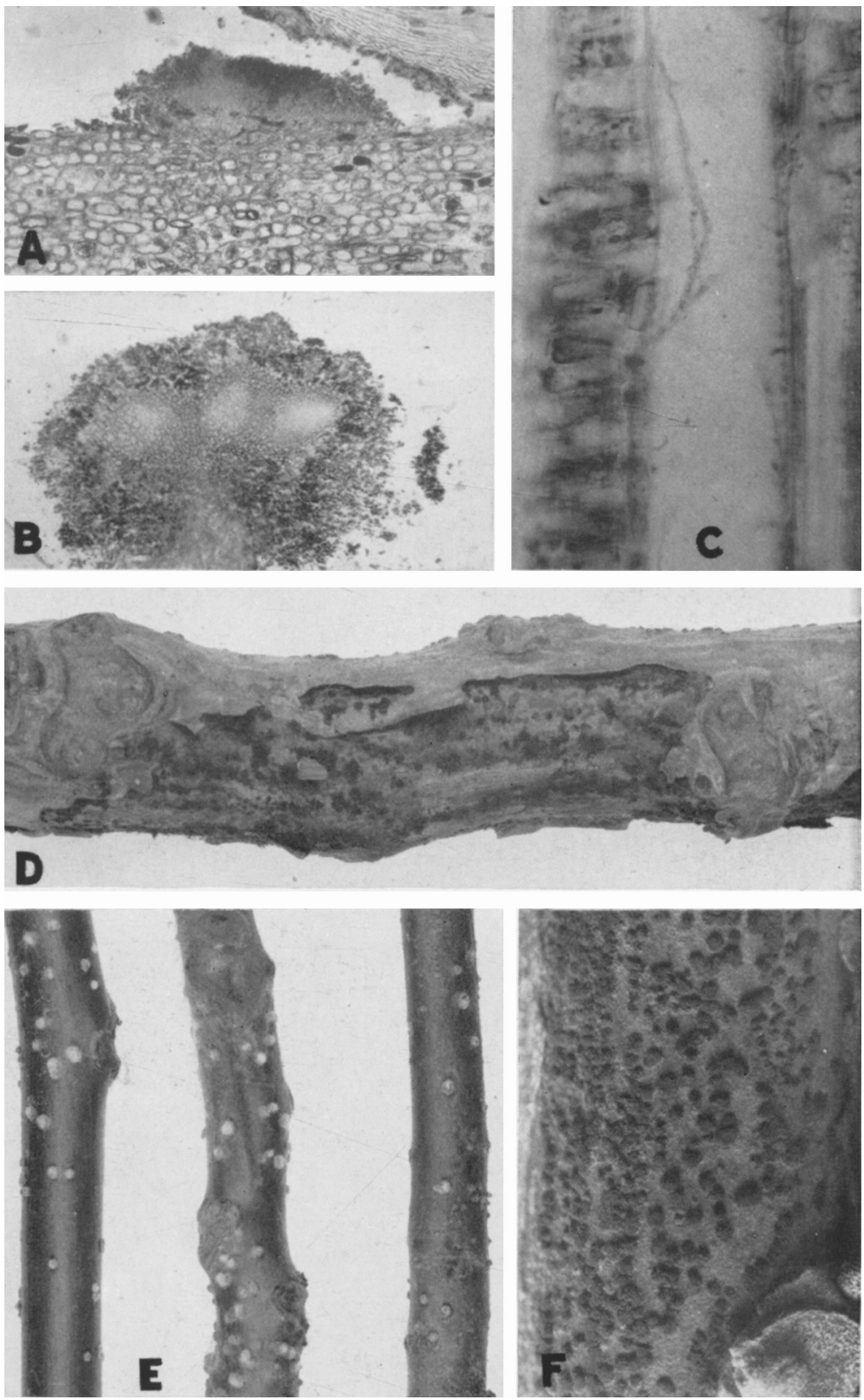

Plate 3. $-A$, A sporodochium of the branch-wilt fungus on the cortex of diseased walnut bark (longitudinal section, $\times 80$ ). The loosened periderm is visible above the sporodochium. $B$, A sporodochium produced on cornmeal agar (longitudinal section, $\times 80)$. $C$, Mycelium of the branch-wilt pathogen in a vessel $(\times 225) . D$ and $F$, Immature and mature sporodochia on the cortex of branches $(D, \times 2 ; F, \times 5)$. $E$, From left to right, sporodochia produced by the walnut, chestnut, and grapefruit isolates on artificially inoculated, steamsterilized walnut twigs. 

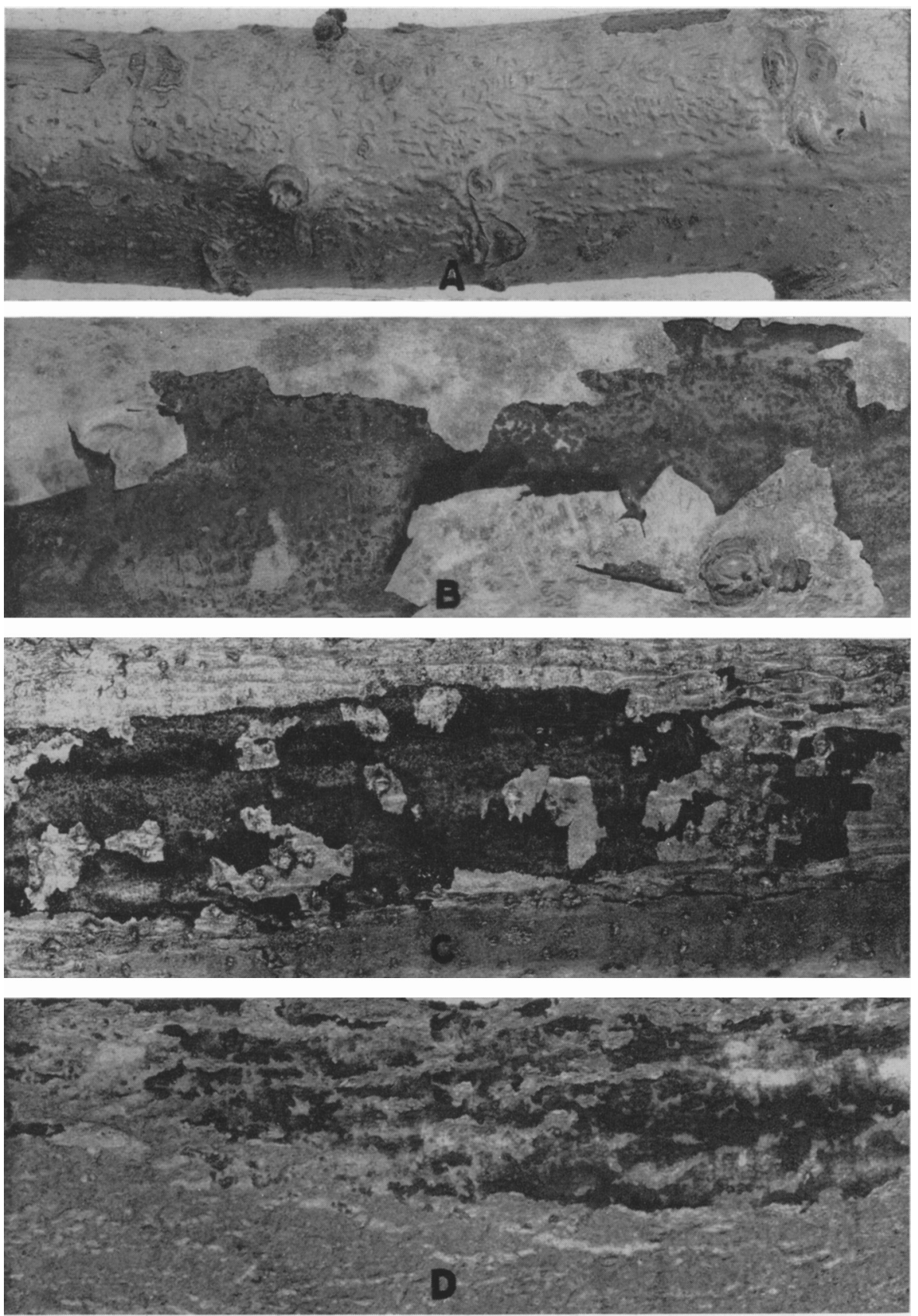

Plate 4.-A, Raising of the periderm of a walnut branch by numerous sporodochia on the underlying cortex. $B, C, D$, Comparison of the sooty spore deposits of the pathogen on walnut, chestnut, and lemon branches, respectively. 


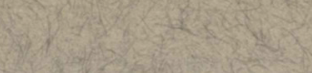

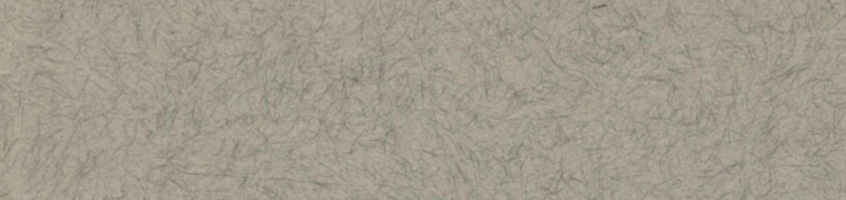

(x)

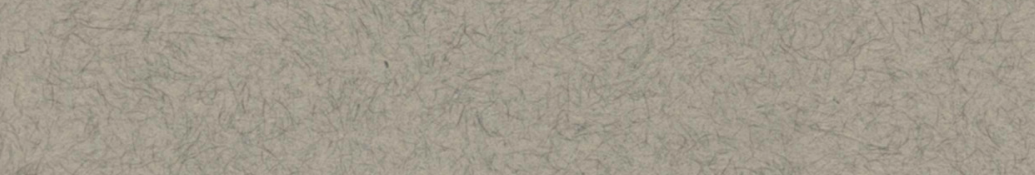

\section{(x)}

to

(5)

$$
\begin{aligned}
& \text { 1. ON. }
\end{aligned}
$$

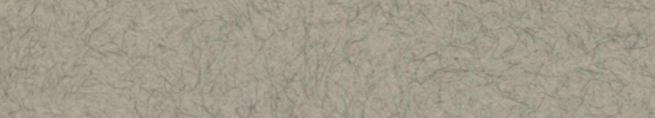

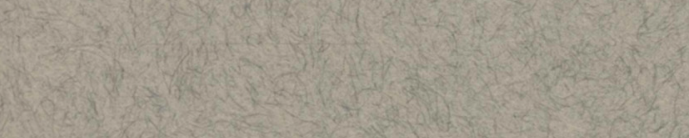

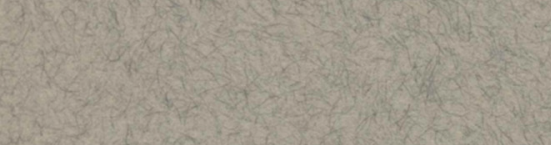

$\operatorname{lin} 2$

3.

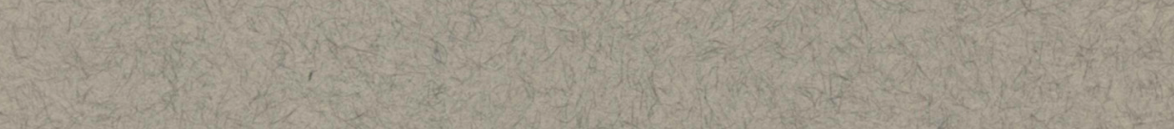

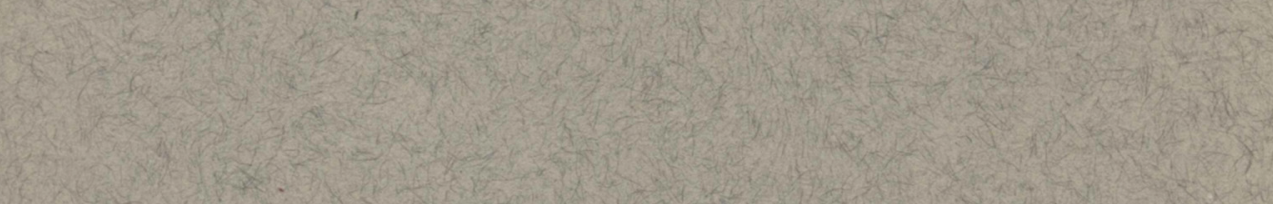

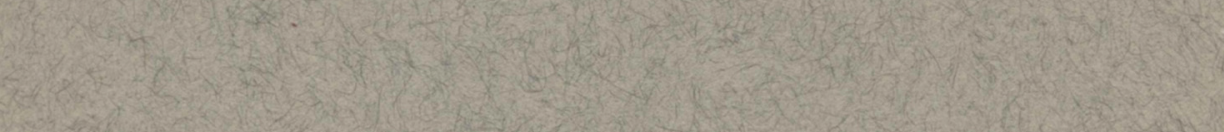

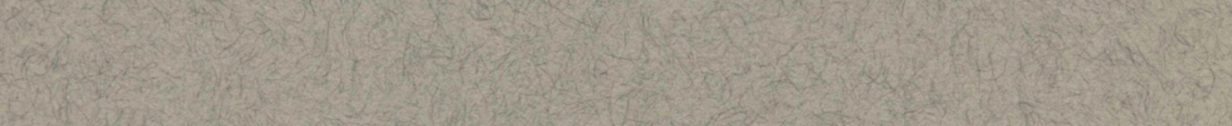

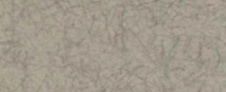

$x_{1,3}$

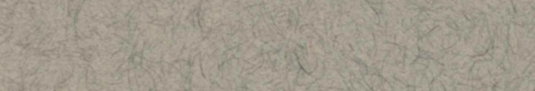

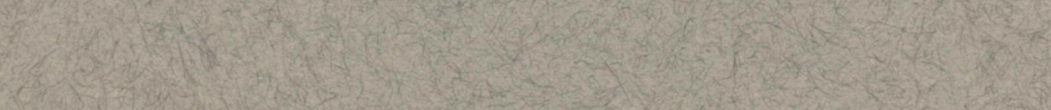

